\title{
Zinc Finger Protein Gfi-1b
}

National Cancer Institute

\section{Source}

National Cancer Institute. Zinc Finger Protein Gfi-1b. NCI Thesaurus. Code C26384.

Zinc finger protein Gfi-1b (330 aa, $237 \mathrm{kDa}$ ) is encoded by the human GFI1B gene. This protein is involved in both transcriptional regulation and cell proliferation. 